\title{
Disseminated histoplasmosis in an immunocompetent individual diagnosed with gastrointestinal endoscopy: a case report
}

\author{
Yini Dang ${ }^{1,2 \dagger}$, Longfeng Jiang ${ }^{1 \dagger}$, Jianfu Zhang ${ }^{3}$, Beijing Pan ${ }^{4}$, Guoqin Zhu ${ }^{5}$, Feipeng Zhu ${ }^{6}$, Zhe Guo ${ }^{7}$, Biao Wang ${ }^{8}$,
} Guoxin Zhang ${ }^{2}$, Yali Weng ${ }^{1 *}$ (D) and Jun $\mathrm{Li}^{1}$

\begin{abstract}
Background: Histoplasmosis is one of the invasive fungal infections and presents with symptoms mainly in the lungs. Disseminated histoplasmosis $(\mathrm{DH})$ is rare and its lesions in the gastrointestinal tract are even uncommon. The concomitant involvement of the upper and lower gastrointestinal tract has never been described in the immunocompetent individuals.

Case presentation: A 44-year-old immunocompetent Chinese man presented with fever, hepatosplenomegaly, fungal esophagitis and protuberant lesions with central depression and erosion along the mucous membrane of the colon. The patient was diagnosed as disseminated histoplasmosis by gastrointestinal endoscopy.

Conclusions: Histoplasmosis should be taken caution in patients with fever and hepatosplenomegaly. Actions should be taken to avoid its disseminated infection associated high mortality.
\end{abstract}

Keywords: Disseminated histoplasmosis, Endoscopy, Esophagus, Colon

\section{Background}

Histoplasmosis is one of the invasive fungal infections and presents with symptoms mainly in the lungs [1]. Disseminated histoplasmosis $(\mathrm{DH})$ is rare and its lesions in the gastrointestinal tract are even uncommon [1-3]. The concomitant involvement of the upper and lower gastrointestinal tract has never been described in the immunocompetent individuals. Here, a case of disseminated histoplasmosis in the non-endemic area was presented in an immunocompetent patient diagnosed by gastrointestinal endoscopy.

\section{Case presentation}

A 44-year-old Chinese man admitted to Chaohu Hospital of Anhui Medical University in April 3rd 2018 and presented with intermittent high-grade fever (Tmax of

* Correspondence: wengyali@njmu.edu.cn

†Yini Dang and Longfeng Jiang contributed equally to this work.

${ }^{1}$ Department of Infectious Diseases, The First Affiliated Hospital of Nanjing

Medical University, No.300 of Guangzhou Road, Nanjing 210029, China

Full list of author information is available at the end of the article $39.5^{\circ} \mathrm{C}$ ) with chills and rigor since January 2018. Before his admission to this hospital, he was treated with outpatient intermittent cephalosporin therapy, however no obvious curative effect was observed. After admission, ultrasonography and CT both revealed hepatosplenomegaly, and bone marrow tests demonstrated macrophages which abnormally engulf red blood cells and platelets and thrombocytopenia. Then this patient received piperacillin/tazobactam $3.375 \mathrm{~g} / \mathrm{q} 8 \mathrm{~h}$ for 5 days and no improvement was observed. Afterwards the antibiotics were upgraded to biapenem $0.3 \mathrm{~g} / \mathrm{qd}$ combined with teicoplanin $0.2 \mathrm{~g} / \mathrm{qd}$ for 5 days. During his stay in Chaohu Hospital of Anhui Medical University, the patient lost $8 \mathrm{~kg}$ of weight and no significant curative effect was achieved. Due to this condition, the patient was transferred to the First Affiliated Hospital of Nanjing Medical University.

On his admission to our hospital, vital signs showed temperature of $39.4^{\circ} \mathrm{C}$, heart rate of $110 / \mathrm{min}$, respiration of $22 / \mathrm{min}$ and blood pressure of $110 / 68 \mathrm{mmHg}$. The 
patient showed no palpable lymph nodes on the neck, the liver was $12 \mathrm{~cm}$ below the right rib border and $8 \mathrm{~cm}$ below the xiphoid, spleen was $11 \mathrm{~cm}$ below the left rib border. Medical history suggested there was no underlying disease, no smoking, no alcohol or illicit drug abuse.

Laboratory examinations on admission revealed hemoglobin of $112 \mathrm{~g} / \mathrm{L}$, red blood cell (RBC) counts $4.41 \times 10^{\wedge} 12 / \mathrm{L}$, platelet counts $56 \times 10^{\wedge} 9 / \mathrm{L}$ and white blood cell $(\mathrm{WBC})$ counts $3.62 \times 10^{\wedge} 9 / \mathrm{L}$, liver enzymes $\gamma$-GGT 98.4 U/L, ALP 329 U/L, TBil $35.4 \mu \mathrm{mol} / \mathrm{L}$, DBil $14.0 \mu \mathrm{mol} / \mathrm{L}$, UBil $21.4 \mu \mathrm{mol} / \mathrm{L}$, inflammatory markers (PCT $0.26 \mathrm{ng} / \mathrm{mL}$, CRP $34.0 \mathrm{mg} / \mathrm{L}$, FERR $1101.8 \mathrm{ng} / \mathrm{mL}$ ), G test of $238.1 \mathrm{pg} / \mathrm{mL}$, GM test of 0.375 , immunoglobulin levels comprised IgG $11.7 \mathrm{~g} / \mathrm{L}$, IgA $1.23 \mathrm{~g} / \mathrm{L}, \operatorname{IgM} 2.9 \mathrm{~g} / \mathrm{L}$, normal complement levels with C3 $0.71 \mathrm{~g} / \mathrm{L}, \mathrm{C} 40.167 \mathrm{~g} / \mathrm{L}$. Lymphocyte subsets comprised $67 \%$ total $\mathrm{T}$ cell, $29 \%$ Helper T cell, 33\% Suppressor T cell, CD4+/CD8+ 0.89, total $\mathrm{T}$ cell count 323 cells $/ \mu \mathrm{l}$, Helper T cell count 148 cells $/ \mu$ l, Suppressor T cell count 167 cells $/ \mu l, 3.7 \%$ early activated stage $\mathrm{T}$ cell, $6.91 \%$ middle activated stage $\mathrm{T}$ cell, $44.42 \%$ late activated stage $\mathrm{T}$ cell (see Additional file 1: Table S1).

No significant change was detected in terms of other blood tests including kidney function tests, tumor markers (AFP, CEA, CA199, CA-724, CYFRA21-1, NSE, TPSA, FPSA), autoantibodies, antibodies related to infectious diseases (HBV, HCV, HIV, CMV-DNA, EBV-DNA, T-SPOT).
Ultrasonography revealed hepatosplenomegaly. The whole body was scanned with ${ }^{18} \mathrm{~F}$-fluorodeoxyglucose (FDG) positron emission tomography with computed tomography $\left({ }^{18} \mathrm{~F}\right.$-FDG PET/CT) and showed that the length of liver was $245.543 \mathrm{~mm}$ and length of spleen was $187.935 \mathrm{~mm}$. The enlarged liver and spleen showed mild increased metabolic activity according to the results of ${ }^{18}$ F-FDG PET/CT. Diffused slight hyper-metabolism in whole body bone marrow and multiple lymph nodes around porta hepatis and retroperitoneum were also depicted. As a $0.8 \mathrm{~cm}$ polyp-like lesion was detected in the small intestine with increased metabolism in the FDG PET/CT images, further gastrointestinal endoscopy was arranged (see Fig. 1a). PET/CT showed no significant central nervous system involvement and no lesion in lung, therefore a lumbar puncture and percutaneous lung puncture biopsy were not conducted.

Gastroscopy showed consecutive sheets of white bean curd-like substance attached to the esophageal mucosa, referring fungal esophagitis (see Fig. 1b). Colonoscopy showed protuberant lesions with central depression and erosion along the mucous membrane of the colon (Fig. 1c). Biopsy specimens of the colon identified numerous yeast-like structures containing increased numbers of histiocytes staining positive for PAS stain, indicating granulomatous inflammation induced by mycotic infection (see Fig. 2a, b and c).

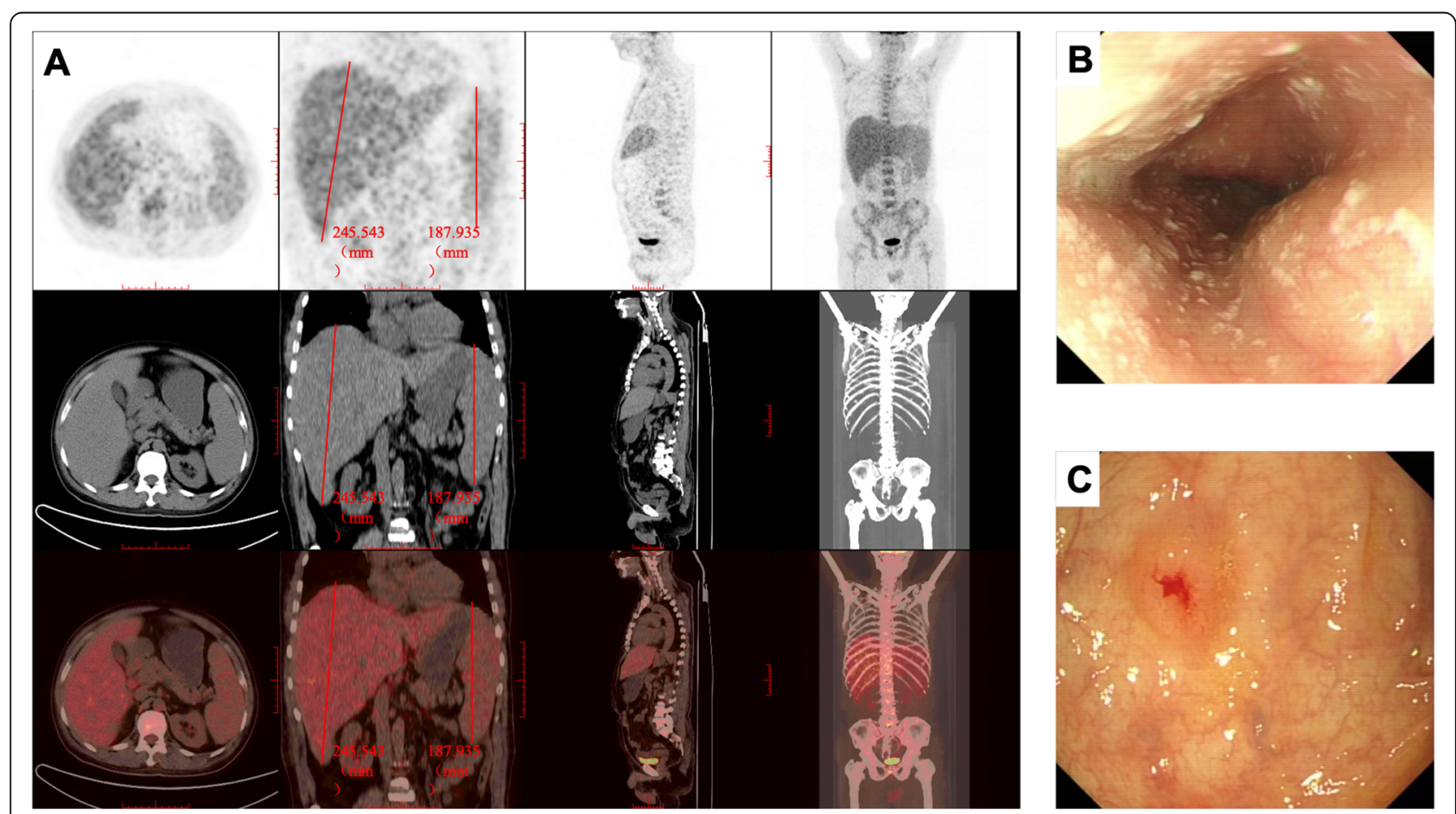

Fig. 1 a Increased FDG uptake in liver and spleen; the length of liver was $245.543 \mathrm{~mm}$ and the length of spleen was $187.935 \mathrm{~mm}$ in the ${ }^{18} \mathrm{~F}$-FDG PET/ CT images before intervention. $\mathbf{b}$ esophageal mucosa was covered consecutive sheets of white bean curd-like substance under gastrointestinal endoscopy. c colon mucosa studded with protuberant lesions with central depression and erosion under gastrointestinal endoscopy 

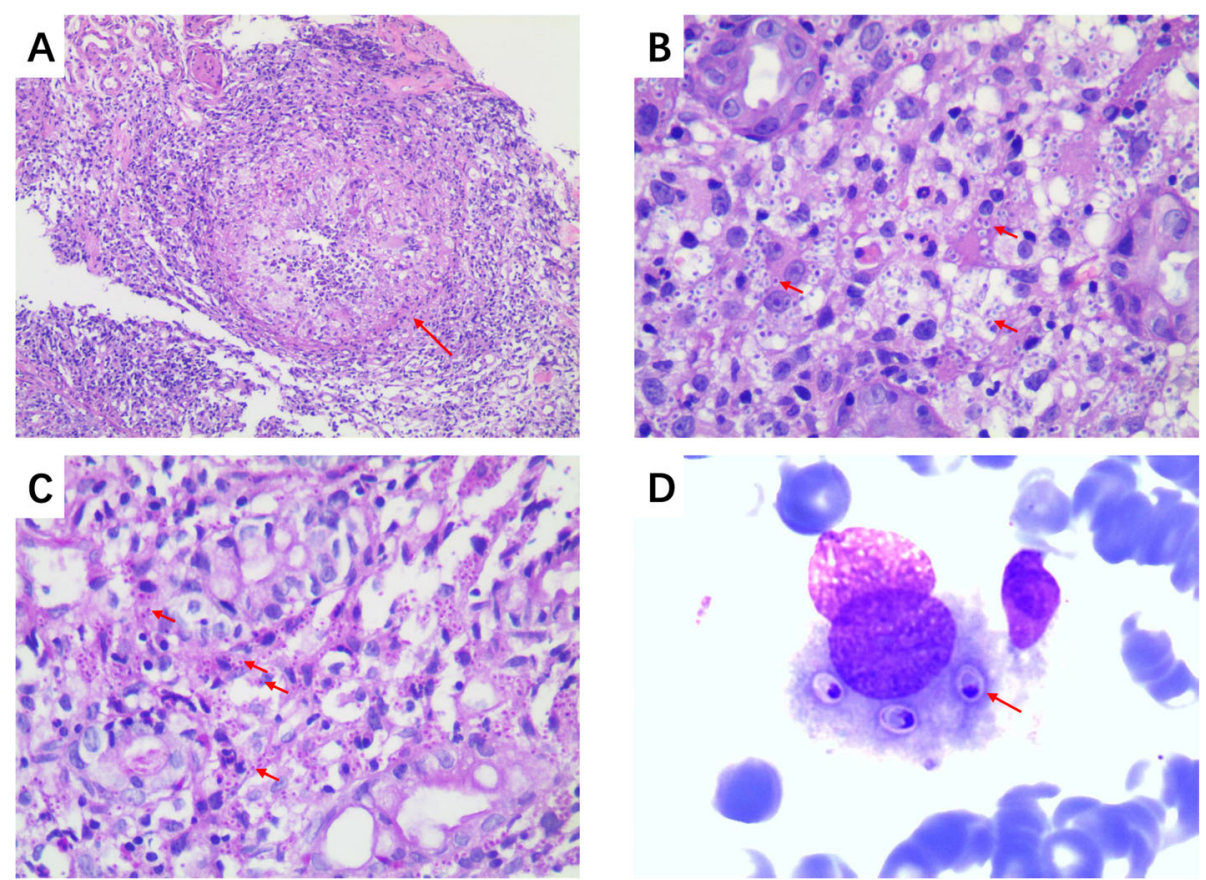

Fig. 2 a Granuloma formation (red arrow, $\times 400)$. b HE stain of bone marrow puncture images before treatment $(\times 1000)$. c PAS stain (red arrows, $\times 400)$. d HE stain of bone marrow puncture images before treatment $(\times 1000)$

Blood Routine, Biochemical Test, FERR were repeated during hospitalization and revealed progressive pancytopenia (see Additional file 1: Table S2). Hematoxylin and eosin stained bone marrow demonstrated oval or round organisms with amaranth nuclei and capsule-like unstained halos around these organisms observed in the cytoplasm of phagocytes. These observations were highly recommended of histoplasmosis capsulatum (see Fig. 2d).

The clinical manifestation, medical history, physical examinations and the related examinations confirmed his diagnosis of disseminated histoplasmosis involved in the digestive tract.

The patient started to receive intravenous amphotericin B deoxycholate at an initial dose of $7 \mathrm{mg} / \mathrm{d}$ in Day $1,30 \mathrm{mg} / \mathrm{d}$ in Day 2, $50 \mathrm{mg} / \mathrm{d}$ in Day 3 and then every $5 \mathrm{mg} /$ day was added till the dose reached 110 $\mathrm{mg} / \mathrm{d}$ (approximately $1.5 \mathrm{mg} / \mathrm{kg}$ ) [4]. In Day 25, the follow-up CT scan showed the size of liver and spleen narrowed (see Additional file 2: Figure S1). Gastrointestinal endoscopy showed esophageal and colon mucosa was normal as well (Additional file 2: Figure S2). Residual fungal cell walls were seen in both liver tissues and colon mucosa pathology specimens (see Additional file 2: Figures S3 and S4). H. capsulatum cannot be detected in the bone marrow aspirate (see Additional file 2: Figure S5). In Day 26, a total dose of amphotericin B deoxycholate reached $2400 \mathrm{mg}$, then it was replaced with itraconazole $200 \mathrm{mg}$ bid orally. Two days after amphotericin B deoxycholate treatment, his temperature returned to normal. The liver narrowed to $7 \mathrm{~cm}$ below the right rib border and $4 \mathrm{~cm}$ below the xiphoid, the spleen was $6 \mathrm{~cm}$ below the left rib border in Day 36. The liver narrowed to $3 \mathrm{~cm}$ below the right rib border and the spleen was 3 $\mathrm{cm}$ below the left rib border in Day 44. In addition, the results of Blood Routine returned to normal (see Additional file 1: Table S1).

\section{Discussion and conclusion}

According to the literature, only nine $\mathrm{DH}$ cases in the digestive tract of immunocompetent patients have been reported, among which none of the cases reported concomitant involvement of esophagus and colon (see Table 1) [2, 5-9]. This is a rare and typical DH case encroaching on esophagus, colon, liver, spleen and bone marrow in an immunocompetent individual. In this case, underlying chronic disease or underlying immunodeficiency was not observed. Results of laboratory examinations, bone marrow aspirate, $\mathrm{PET} / \mathrm{CT}$, gastrointestinal endoscopy and pathological examinations were collected before and after intervention. Significant improvement was observed with the application of amphotericin B deoxycholate. However, the transjugular liver puncture cannot be performed due to the limited technical support and the percutaneous liver puncture was not carried out due to his extremely low platelet level. 
Table 1 Disseminated histoplasmosis involved in digestive tract in immunocompetent individuals

\begin{tabular}{|c|c|c|c|c|c|c|c|}
\hline Articles & Country & Gender & Age & Symptoms & Involvement & Intervention & Prognosis \\
\hline Yang 2013 [5] & China & Male & 33 & Fever, weight loss & $\begin{array}{l}\text { Bone marrow, } \\
\text { spleen, colon }\end{array}$ & $\begin{array}{l}\text { Amphotericin B deoxycholate } \\
\text { for a total of } 2 \mathrm{~g} \text {, shifted to oral } \\
\text { itraconazole }(200 \mathrm{mg} \text { bid) }\end{array}$ & Recovery \\
\hline Badyal 2013 [6] & India & Male & 62 & $\begin{array}{l}\text { Abdominal distension, } \\
\text { abdominal pain, constipation }\end{array}$ & Colon & $\begin{array}{l}\text { Tazocin } 4.5 \mathrm{~g} \text { and metronidazole } \\
500 \mathrm{mg} \text { q8h, amphotericin B } \\
500 \mathrm{mg} \text { and itraconazole } 200 \mathrm{mg} \\
\text { qd for } 15 \text { days }\end{array}$ & Recovery \\
\hline Chaudhari 2013 [7] & USA & Female & 22 & Fever, weight loss, dysphagia, & Esophagus & Thoracotomy & Recovery \\
\hline Wu 2015 [2] & China & Male & 29 & Fever, cough & Colon & Not reported & $\begin{array}{l}\text { Not } \\
\text { reported }\end{array}$ \\
\hline \multirow[t]{4}{*}{ Zhu 2016 [8] } & \multirow[t]{4}{*}{ China } & Male & 61 & $\begin{array}{l}\text { Abdominal pain, abdominal } \\
\text { distention, anorexia }\end{array}$ & Colon & No anti-fungal drugs & Recovery \\
\hline & & Male & 33 & $\begin{array}{l}\text { Fever, anorexia, pharyngalgia, } \\
\text { cough, expectoration, weight } \\
\text { loss }\end{array}$ & $\begin{array}{l}\text { Bone marrow, colon, } \\
\text { terminal ileum }\end{array}$ & $\begin{array}{l}\text { Amphotericin B deoxycholate for } \\
\text { a total of } 1.47-2.79 \mathrm{~g} \text {, shifted to } \\
\text { itraconazole }(200 \mathrm{mg} \text { bid) for } 6 \mathrm{~m}\end{array}$ & Recovery \\
\hline & & Male & 59 & $\begin{array}{l}\text { Fever, abdominal pain, abdominal } \\
\text { distention, anorexia, weight loss }\end{array}$ & $\begin{array}{l}\text { Bone marrow, colon, } \\
\text { terminal ileum }\end{array}$ & $\begin{array}{l}\text { Amphotericin B deoxycholate for } \\
\text { a total of } 1.47-2.79 \mathrm{~g} \text {, shifted to } \\
\text { itraconazole }(200 \mathrm{mg} \text { bid) for } 6 \mathrm{~m}\end{array}$ & Recovery \\
\hline & & Male & 28 & $\begin{array}{l}\text { Fever, abdominal pain, abdominal } \\
\text { distention, diarrhea, weight loss }\end{array}$ & $\begin{array}{l}\text { Bone marrow, colon, } \\
\text { terminal ileum }\end{array}$ & $\begin{array}{l}\text { Amphotericin B deoxycholate for } \\
\text { a total of } 1.47-2.79 \mathrm{~g} \text {, shifted to } \\
\text { itraconazole }(200 \mathrm{mg} \text { bid) for } 6 \mathrm{~m}\end{array}$ & Lost \\
\hline Sharma 2017 [9] & India & Male & 45 & Right-sided pleural effusion & Lung, ileum & $\begin{array}{l}\text { Amphotericin B deoxycholate, } \\
\text { details not reported }\end{array}$ & Recovery \\
\hline
\end{tabular}

The diagnosis of this case was based on the observation of $\mathrm{H}$. capsulatum in both colon mucosa pathology and bone marrow aspirate. Colon biopsy specimens showed granuloma formation. According to the previous study, only $8 \%$ of histoplasmosis showed fully developed granuloma, suggesting that this patient is an immunocompetent host. Furthermore, ${ }^{18}$ F-FDG PET/CT also suggested hematological disease in this case rather than infectious disease. ${ }^{18}$ F-FDG accumulated not only in malignant tumors but also in both infectious and noninfectious inflammatory lesions. There were overlaps between FDG uptake of malignant lesions and certain infectious processes due to the presence of macrophages. Tuberculosis and histoplasmosis infections lead to active granulomatous processes and may mimic malignant lesion with accumulated FDG uptake [10, 11]. Therefore, it is difficult to identify malignant tumors from infectious inflammatory lesions. It is the reason that this case was diagnosed with pathological examinations instead of ${ }^{18} \mathrm{~F}$-FDG PET/CT. In addition, PCR and specific antigen test cannot be performed since there was limited technical support in our hospital. However, it is strongly suggested to perform PCR and specific antigen test in the future to further support the diagnosis of this disease [12].

This patient lived in a non-endemic area and visited Vietnam 8 years ago. Immunocompetent adults who exposed to the infectious organisms, the important risk factor for DH, may progress slower than immunocompromised or immunosuppressed individuals
[13]. To the best of our knowledge, one of the studies reported that $\mathrm{DH}$ was diagnosed after 40 years [14]. Therefore, the natural history of this disease may be caused by the accumulation of fungal organisms in different organs or tissues, and it can be trigged by the variation of the immune micro-environment.

\section{Supplementary information}

Supplementary information accompanies this paper at https://doi.org/10. 1186/s12879-019-4542-x.

Additional file 1. Laboratory examination during the process of diagnose and intervention. Summary of laboratory examination during the process of diagnose and intervention.

Additional file 2. CT images, gastrointestinal endoscopy images, colonic biopsy images, liver biopsy images and bone marrow puncture images after intervention.

\begin{abstract}
Abbreviations
${ }^{18} \mathrm{~F}$-FDG PET/CT: ${ }^{18} \mathrm{~F}$-fluorodeoxyglucose positron emission tomography with computed tomography; AFP: Alpha-fetoprotein; CA199: Carbohydrate antigen 19-9; CA-724: Carbohydrate antigen 724; CEA: Carcinoembryonic antigen; CRP: C-reactive protein; CYFRA21-1: Cytokeratin 19 fragments; DBil: Direct bilirubin; DH: Disseminated histoplasmosis; FERR: Serum ferritin; FPSA: Free prostate specific antigen; HBV: Hepatitis B virus; HCV: Hepatitis C virus; HIV: Human immunodeficiency virus; NSE: Neuron-specific enolase; PAS stain: Periodic Acid-Schiff stain; PCT: Procalcitonin; RBC: Red blood cell; TBil: Total bilirubin; TPSA: Total prostate specific antigen; T-SPOT: Enzymelinked immunospot assay; UBil: Undirect bilirubin; WBC: White blood cell
\end{abstract}




\section{Authors' contributions}

YD and LJ: Literature research, Manuscript preparation. JZ: pathological evaluation of bone marrow puncture. BP: pathological evaluation of colon tissue. GZ: gastrointestinal endoscopy. FZ and ZG: CT and PET/CT diagnosis. BW and GZ: treatment support. JL and YW: Manuscript final version approval. All authors have read and approved the manuscript.

\section{Funding}

This work was funded by the National Science Foundation of Jiangsu Province (No. BK20161059). The funding body had no role in the design of the study and collection, analysis, and interpretation of data or in writing the manuscript.

\section{Availability of data and materials}

All available data is presented within the manuscript and additional supporting files.

\section{Ethics approval and consent to participate}

Not applicable.

\section{Consent for publication}

Written informed consent was obtained from the patient for publication of this Case Report and any accompanying images. A copy of the written consent is available for review by the Editor of this journal.

\section{Competing interests}

The authors declare that they have no competing interests.

\section{Author details}

'Department of Infectious Diseases, The First Affiliated Hospital of Nanjing Medical University, No.300 of Guangzhou Road, Nanjing 210029, China. ${ }^{2}$ Department of Gastroenterology, The First Affiliated Hospital of Nanjing Medical University, Nanjing, China. ${ }^{3}$ Department of Hematology, The First Affiliated Hospital of Nanjing Medical University, Nanjing, China. ${ }^{4}$ Department of Pathology, The First Affiliated Hospital of Nanjing Medical University, Nanjing, China. ${ }^{5}$ Department of Geriatric Gastroenterology, The First Affiliated Hospital of Nanjing Medical University, Nanjing, China. ${ }^{6}$ Department of Medical Imaging, The First Affiliated Hospital of Nanjing Medical University, Nanjing, China. 'Department of nuclear medicine, The First Affiliated Hospital of Nanjing Medical University, Nanjing, China. ${ }^{8}$ Department of Pharmacy, The First Affiliated Hospital of Nanjing Medical University, Nanjing, China.

Received: 25 March 2019 Accepted: 9 October 2019

Published online: 21 November 2019

\section{References}

1. Kahi C, Wheat J, Allen SD, et al. Gastrointestinal histoplasmosis. Am J Gastroenterol. 2005;100:220-31.

2. Wu Y, Zhuang J, Chen X. Histoplasmosis identified by colonoscopy: a case report. Baotou Med Coll J. 2015:31:109-10.

3. Colaiacovo R, de Castro ACF, Shiang C, et al. Disseminated histoplasmosis: a rare cause of multiple ulcers in the gastrointestinal tract. Endoscopy. 2011; 43:E216.

4. Wheat $\amalg$, Freifeld $A G$, Kleiman MB, et al. Clinical practice guidelines for the management of patients with histoplasmosis: 2007 update by the Infectious Diseases Society of America. Clin Infect Dis. 2007;45:807-25.

5. Yang B, Lu L, Li D, et al. Colonic involvement in disseminated histoplasmosis of an immunocompetent adult: case report and literature review. BMC Infect Dis. 2013;13:143-6.

6. Badyal RK, Gupta R, Vaiphei K. Diffuse perforated necrotising amoebic colitis with histoplasmosis in an immunocompetent individual presenting as an acute abdomen. BMJ Case Rep. 2013. https://doi.org/10.1136/bcr-2013-009059.

7. Chaudhari D, Mckinney J, Hubbs D, et al. Mediastinal histoplasmosis presenting as dysphagia: a case report with literature review. Clin J Gastroenterol. 2013;6:315-8.

8. Zhu L, Wang J, Wang Z, et al. Intestinal histoplasmosis in immunocompetent adults. World J Gastroenterol. 2016;22:4027-33.

9. Sharma R, Lipi L, Gajendra S, et al. Gastrointestinal histoplasmosis: a case series. Int J Surg Pathol. 2017;25:592-8.

10. Sharma P, Mukherjee A, Karunaithi S, et al. Potential role of ${ }^{18} \mathrm{~F}-\mathrm{FDG}$ PET/CT in patients with fungal infections. AJR Am J Roentgenol. 2014;203:180-9.
11. Perko R, Messinger $Y$, Moertel C. Pseudometastasis secondary to histoplasmosis infection: false-positive PET/CT findings. Pediatr Blood Cancer. 2010;54:621-3.

12. Klein M, Khan M, Salinas JL, et al. Disseminated pulmonary histoplasmosis in immunocompetent patients: a common epidemiological exposure. BMJ Case Rep. 2019;12:1-13.

13. Azar MM, Hage CA. Clinical perspectives in the diagnosis and management of histoplasmosis. Clin Chest Med. 2017;38:403-15.

14. Richaud C, Chandesris MO, Lantemier F, et al. Imported African histoplasmosis in an immunocompetent patient 40 years after staying in a disease-endemic area. Am J Trop Med Hyg. 2014;91:1011-4.

\section{Publisher's Note}

Springer Nature remains neutral with regard to jurisdictional claims in published maps and institutional affiliations.

\section{Ready to submit your research? Choose BMC and benefit from:}

- fast, convenient online submission

- thorough peer review by experienced researchers in your field

- rapid publication on acceptance

- support for research data, including large and complex data types

- gold Open Access which fosters wider collaboration and increased citations

- maximum visibility for your research: over $100 \mathrm{M}$ website views per year

At BMC, research is always in progress.

Learn more biomedcentral.com/submissions 